\title{
Storage of Pacific oysters Crassostrea gigas in recirculating tank: ammonia excretion and potential nitrification rates
}

\author{
Buzin Florence ${ }^{1,2,{ }^{*}}$, Dupuy Beatrice ${ }^{1}$, Lefebvre Sebastien ${ }^{3}$, Barille Laurent ${ }^{2}$, Haure Joel ${ }^{1}$
}

${ }^{1}$ IFREMER, Laboratoire de Génétique et Pathologie, Polder des Champs, Bouin, F-85230, France

${ }^{2}$ LUNAM Université, Université de Nantes, Mer Molécules Santé EA 2160, Faculté des Sciences et des Techniques, BP 92208, 2 rue de la Houssinière, Nantes, F-44322, France

${ }^{3}$ Université de Lille 1 Sciences et Technologies, CNRS, UMR 8187 Laboratoire d'Océanographie et de Géoscience, Wimereux Marine Station, 28 av. Foch, Wimereux, F-62930, France

* Corresponding author : Florence Buzin, Tel.: +33 6199227 74. ;

email address : florence.buzin@orange.fr

\begin{abstract}
:
In response to the closure of shellfish production sites due to increasing occurrence of toxic algal blooms, land-based recirculating aquaculture systems (RAS) could be used by producers to store a proportion of their stock temporarily. An RAS prototype was tested in this study to store Pacific oyster Crassostrea gigas over a range of temperatures. In such systems, the water temperature is a variable that could influence the bivalve excretion rate of ammonia, the concentration of which may become critical for the water quality. In this study, we first estimated the total ammonia nitrogen (TAN, N-NH4+ + $\mathrm{N}-\mathrm{NH} 3$ ) excretion of the Pacific oyster and then investigated whether the bacterial population associated with the oysters could act as a natural biofilter by measuring the potential nitrification rate (PNR) of the shell. The TAN excretion rate varied significantly with temperature. The PNRs were significantly different depending on the shell surface considered with a PNR of $0.42 \pm 0.11$ (SD) nmol N cm-2 h-1 for the internal part, $0.96 \pm 0.15$ (SD) nmol N cm-2 $\mathrm{h}-1$ for the external part of the shell. In addition, a 5-week experiment was conducted with a $180 \mathrm{~kg}$ of oyster stock stored in a $1900 \mathrm{~L}$ RAS to monitor TAN concentration and to establish a TAN budget at the level of an oyster population. The TAN concentration sharply declined in the RAS after 6 days and a stable concentration of $3.3 \pm 0.91$ (SD) $\mu \mathrm{mol} \mathrm{N} \mathrm{L}-1$ was reached till the end of the experiment. This measurement, as well as the estimation of a theoretical TAN budget based on the previous experiments, showed that the PNR and some other associated processes were sufficient to counteract the ammonia fluxes excreted by the oysters. This result underlines the significant role played by the nitrifying bacterial population colonizing the bivalve shell and suggests that such an oyster stock could be stored in a recirculating tank without the addition of a biofilter, which would represent a real economic advantage.
\end{abstract}




\section{Highlights}

- Oyster shell harboured a bacterial population with nitrifying activity. The PNR of oyster shell was higher than for other suspension-feeding bivalves. The TAN excretion could be covered by the bacterial nitrifying activity. Oyster stock could be stored in a RAS without the addition of a biofilter.

Keywords: Crassostrea gigas, Ammonia excretion, Nitrification rate, Recirculating system, Temperature 


\section{1- Introduction}

The Pacific oyster Crassostrea gigas represents a large part of the French mollusc production with 112,760 tons in 2007 (FAO, 2009) but the occurrence of productionsite closures due to water quality crises is now destabilizing this economically important shellfish activity more frequently. Indeed, shellfish farmers are faced with toxic algal blooms that contaminate bivalves by ingestion of microalgae. These events can be observed all along the French coast from Northern Brittany, with summer episodes of Alexandrium minutum to the Thau lagoon in the Mediterranean, with autumn episodes of $A$. catenella (Lassus et al., 2004). Shellfish farmers are thus subjected to major constraints owing to legislation prohibiting sales during toxic algal blooms and must also face consumer mistrust of bivalves (Shumway, 1990). The analysis of the duration and the frequency of production-site closures recorded on French coasts between 1984 and 2003 (Belin, 2004) reveals that those lasting 15 days represented up to $50 \%$ of the total closures (Buzin et al., 2011). To deal with this problem, risk management must be seriously taken into account and research must be carried out to develop sustainable solutions. The storage of bivalves in recirculating aquaculture systems (RAS), already considered for bacterial depuration (Boulter et al., 1999; De Abreu Corrêa et al., 2007), could be an opportunity to cope with a temporarily unhealthy environment. A pre-requisite to apply this technique is however the availability of uncontaminated seawater. Shellfish farmers may store a proportion of their stock to keep selling during short periods of 15 to 30 days, generating income to cover their operating expenses. For average-sized companies with an annual production of 30 tons, (Tissot et al., 2012), this fraction could represent from five hundred kilos to one ton (Chagneau, pers. com.). Usually, RAS are used for the on-growing of aquatic organisms in a controlled environment, with 
the objective of high economic productivity per unit volume of rearing space (Timmons and Ebeling, 2007). The aquatic organism on-growing in RAS requires the management of multiple water quality variables (Frias and Segovia, 2010; Losordo et al., 1999; Martins et al., 2010). Although these parameters are well determined in fish farming (Timmons and Ebeling, 2007), they must be defined for the storage of bivalves in RAS.

Temperature, with food level, represents a key variable for the oyster energy budget (Alunno-Bruscia et al., 2011), controlling energy acquisition, excretion and metabolic expenditure. Among the different nitrogen forms excreted by bivalves, ammonia represented the major one (more than $50 \%$ ) along with urea and amino acids while a fraction remained unidentified (Hammen et al. 1966; Bayne, 1973). Although ammonia fluxes are assumed to be only a minor component of the oyster energy budget (Barillé et al., 1997; Kesarcodi-Watson et al., 2001 a,b), they can become critical in a recirculating or depuration system. The general trend for bivalves is an increasing ammonia excretion rate with increasing temperature (Bayne and Scullard, 1977; Boulter and Wilson, 1998; Emerson, 1969; Shpigel et al., 1992). The effect of temperature on food acquisition is however different, characterized by an optimum curve; the maximum clearance rate for the Pacific oyster $C$. gigas has been observed for $19^{\circ} \mathrm{C}$ (Bougrier et al., 1995). Although, overall, molluscs appear rather tolerant to high ammonia concentrations (Boardman et al., 2004), various effects of ammonia accumulation have been reported, such as cellular stress (Keppler, 2007), disruption of the filtration activity (Epifanio and Srna, 1975) and a significant decrease in growth (Colt and Armstrong, 1981). Among the different forms of nitrogen, ammonia $\left(\mathrm{N}-\mathrm{NH}_{3}{ }^{+}\right.$ $+\mathrm{N}-\mathrm{NH}_{4}$ ) and nitrite are known to be toxic at high concentration (Colt and Armstrong, 
1981) and remain a major obstacle to conserving good water quality. Epifanio and Srna (1975) determined a 96 hours mean lethal limits for ammonia concentration of $82 \mathrm{mmol}^{-1} \mathrm{~L}^{-1}$ for the oyster Crassostrea Virginica. For a RAS, water renewal should be considered as minimal and is not the solution for a significant elimination of Total Ammonia Nitrogen $\left(\mathrm{NH}_{3}-\mathrm{N}+\mathrm{N}-\mathrm{NH}_{4}{ }^{+}-\mathrm{N}\right)$. Rather, nitrification is usually the preferred process in closed systems to reduce TAN concentration using a biofilter (Aslan and Dahabb, 2008; Chen et al., 2006; Losordo et al., 1999). However, Welsh and Castadelli (2004) have shown that the presence of a bacterial population associated with the shells and tissue of filter-feeding bivalves could have a substantial nitrifying activity but this has not yet been investigated in $C$. gigas.

In this work, we investigated whether the bacterial population associated with C.gigas could act as a natural biofilter in order to counteract the TAN excretion resulting from nitrogen metabolism. [0]Three experiments were set up to assess the ammonia fluxes. (1) We estimated the TAN excretion of the oyster over a range of temperatures. (2) We measured the Potential Nitrification Rate (PNR) of the bivalve shell. (3) These results were used to analyse the TAN concentrations in a $1900 \mathrm{~L}$ RAS prototype (Fig. 1) designed to study the fluxes at the level of a population. With these data, we established a nitrogen budget of an oyster population stored in a RAS, and to see if the efficiency of nitrification by the bacterial population harboured by the oysters could compensate the TAN input linked to their dissolved excretion. 


\section{2- Material and methods}

\subsection{Experiment 1: TAN excretion measurement}

\subsubsection{Experimental set-up}

Experiments were carried out in 2009 at the IFREMER experimental station of Bouin (France) located in a polder used by oyster farmers. It was decided to test the influence of three temperatures $\left(13^{\circ} \mathrm{C}, 16^{\circ} \mathrm{C}\right.$ and $\left.22^{\circ} \mathrm{C}\right)$ on oyster ammonia excretion (Table 1). The temperature ranges were previously determined by studying the oyster filtration activity and considering the economic cost of temperature management in RAS. The food levels were estimated by a Scope For Growth model (Méléder et al., 2001) at a concentration such that oysters stored for 5 weeks would maintain their dry weight (DW). Ninety nine triploids oysters were collected from nearby Bourgneuf Bay on the French Atlantic coast $\left(46-47^{\circ} \mathrm{N}, 1-2^{\circ} \mathrm{W}\right)$ and triploid oysters were chosen to avoid gametogenesis and spawning during the experiments. They were cleaned of epibionts by brushing, placed in a $90 \mathrm{~L}$ tank and acclimated for 5 days for a pre-experimental feeding stage.

\subsubsection{Pre-experimental feeding stage}

The experimental design consisted in distributing the oysters in 9 tanks (90 L) corresponding to 3 replicates per condition tested (Table 1) with 11 individuals per tank and maintained for 5 days at each experimental condition. The 9 tanks ( $\mathrm{C} 1$ to C9) were fed with the diatom Skeletonema costatum at a concentration of $10^{6}$ cells. $\mathrm{mL}^{-1}$ and distributed with a mean flow of $4.6 \mathrm{~L} \cdot \mathrm{h}^{-1}$ for each tank. This microalgae has been successfully used in large-scale units to grow and fatten Pacific oysters (Méléder et al., 2001). 
Twice a day, a water sample was taken from every tank to assess the food levels, which corresponded to 10 measurements per conditions for five days. The water was filtered on a Whatman GF/C filter $(0.7 \mu \mathrm{m})$ and the carbon concentration (C) was subsequently measured using a CHN analyser (Flash EA 1112 NC, Thermo Fisher Scientific Inc., Waltham).

Table 1

\subsubsection{Excretion measurement}

For each condition, the ammonia excretion was measured on six oysters, taken randomly from the 11 individuals. Each oyster was placed individually in a 2-litre beaker filled with filtered seawater $(0.22 \mu \mathrm{m})$. Two empty shells were used as a control. All the beakers were placed in a tank equipped with a heat pump to ensure the thermo-regulation of the water. The beakers were covered to avoid evaporation and maintain stable salinity. Oxygen saturation was ensured by the aeration of each beaker. This aeration could be responsible for the volatilisation of a fraction of the ammonia. However, the ammonia volatilisation rate $\left(\mathrm{N}^{-\mathrm{NH}_{3}}\right.$ form) was low for a seawater $\mathrm{pH}(\mathrm{pH} 8.3)$ and could be estimated between $1.5 \%$ to $13 \%$ of the total nitrogen budget (Briggs and Funge-Smith, 1994; Zimmo et al., 2003). During the experiment, the oysters were starved without water renewal and the bacterial activity was neutralized by the addition of $10 \mathrm{mg} \cdot \mathrm{L}^{-1}$ oxolinic acid per beaker to avoid a loss of TAN $\left(\mathrm{NH}_{3}-\mathrm{N}+\mathrm{N}-\mathrm{NH}_{4}{ }^{+}-\mathrm{N}\right)$ by the nitrification process. The TAN concentration was measured twice a day for 8 days by the indo-phenol blue method (Solorzano, 1969). At the end of the experiment, the dry weight (DW) was determined for each individual by freezing the flesh at $-20^{\circ} \mathrm{C}$ for 48 hours. This step was followed by a lyophilization 
(CHRIST Alpha $1 / 6$ ) at $-54^{\circ} \mathrm{C}$ for 48 hours and then by weighing on a Mettler Toledo balance. The $\mathrm{C}$ and $\mathrm{N}$ content of the tissues were determined on the same samples using the $\mathrm{CHN}$ analyser.

The TAN excretion rate estimated for each oyster was standardized using the allometric relationship established by Bayne and Newell (1983), with an allometric coefficient of 0.6 (Bayne and Svensson, 2006). According to Van Haren and Kooijman (1993), the excretion rate does not depend on the whole body of the oyster but should be related to the soma. For this reason, the excretion rate was standardized to an animal of $1 \mathrm{~g}$ of dry weight of soma (DWsoma) using the following formula $Y_{s}=\left(W_{s} / W_{e}\right)^{b}$. $Y_{e}$ (Bayne and Newell, 1983) where $Y_{s}$ is the standardized rate, $W_{s}$ the standard weight (here $1 \mathrm{~g} D W$ soma), $W_{e}$ the observed weight, $Y_{e}$ the observed rate and $b$ the allometric coefficient (here 0.6 , see above).

The calculation of the weight of the soma was based on the relationship between the stoichiometric $\mathrm{C} / \mathrm{N}$ distribution and the biochemical composition of the tissue (Gnaiger and Bitterlich, 1984). The $\mathrm{C} / \mathrm{N}$ ratio of a bivalve tissue is well correlated to the stock of reserves in the form of glycogen and/or lipids: the higher the $\mathrm{C} / \mathrm{N}$ ratio the higher the reserves (Smaal and Vonck, 1997). According to the observations of Marin Leal et al.(2008), an oyster with a minimum reserve stock presents a $\mathrm{C} / \mathrm{N}$ ratio of ca. 5 , a ratio that we adjusted to 4 in this study. The soma dry weight (DWsoma) was thus calculated as follows:

DWsoma $=$ DWtotal $-[((\mathrm{C} / \mathrm{N})-4) / \mathrm{C} / \mathrm{N}]$. DWtotal

\subsection{Experiment 2: Potential nitrification rates}

This experiment was inspired by the protocol proposed by Welsh and Castadelli (2004) to measure the Potential Nitrification Rate (PNR) of different parts of a 
mollusc, expressed as a flux per unit time. The PNR can be determined as the linear accumulation of nitrite with time (Welsh et Castadelli, 2004) and the results were applied to the oyster shell surface. PNR measurement is not based on ammonia disappearance to avoid underestimation due to a potential volatilisation.

In our experiment, the shells of nine oysters (mean total weight $( \pm$ SD) of $59.35 \pm$ $7.80 \mathrm{~g}$ ) were distributed in six beakers. These oysters had been kept in a RAS for one month to enable the settlement of the bacterial population (Buzin, 2011). Three shells per beaker (in triplicate), were used to measure the PNR of the internal shell surface and three other shells per beaker to measure the external shell surface (in triplicate). The external or the internal parts of half of the shells not being considered, depending on the treatments above, were sterilized with an absorbent paper soaked in ethanol and then rinsed to eliminate the residual ethanol. A beaker without shell was used as a control. All the beakers were filled with 2 litres of filtered seawater $(0.22 \mu \mathrm{m})$ and maintained at $16^{\circ} \mathrm{C}$ with aeration. They were covered to avoid a change in the salinity by evaporation. Each beaker was supplemented with $0.5 \mathrm{mM}$ ammonium chloride as a nitrification substrate (not a limiting concentration in order to provide maximum rates) and $10 \mathrm{mM}$ sodium chlorate was added to inhibit the oxidation of nitrite (Belser and Mays, 1980). Indeed, the nitrification process is made of two stages: the oxidation of ammonia into nitrite and the transformation of nitrite into nitrate. The PNR consists in measuring the capacity of the bacterial population to oxidize the ammonium into nitrite (Mayer et al., 1995). It is thus essential to block the second phase of the nitrification not to underestimate the quantity of nitrite. However, the nitrite concentration measured during the experiment did not reach the toxicity level determined by Epifanio and Srna (1975), with a 96 hours mean lethal tolerance limit at $85 \mathrm{mmol}^{-1} \mathrm{I}^{-1}$, measured on C. virginica. This nitrite concentration was never 
reached during this experiment. The nitrite concentration was measured once a day using the Greiss reaction (Bendschneider and Robinson, 1952) and the nitrate concentration was measured to check the efficiency of the inhibitor. The analyses of $\mathrm{NO}_{3}{ }^{-}$were performed using the MerKoquant Kit ${ }^{\circledR}$ based on the resorcin reaction. In order to measure the total surface area of an oyster shell and to calculate the PNR relative to this surface, a sheet of aluminium was applied to each shell, weighed and the result converted into a surface area $\left(\mathrm{cm}^{2}\right)$ using a pre-established relationship (Welsh and Castadelli, 2004). Finally, the DW of the oysters was determined as described in section 2.1.3.

\subsection{Experiment 3: TAN concentrations in a RAS}

Hundred and eighty kilogrammes of oyster stock, which corresponded to 2655 individuals, was stored in a $1900 \mathrm{~L}$ recirculating aquaculture system consisting of a storage tank where the oysters were placed in baskets (Fig. 1). A part of the flow leaving the storage tank was diverted towards a heat pump (HP) and treated by a UV lamp (UV). The water (FWS) returned to the head of the tank by means of an air-lift system (ALS), which generated the water flow and ensured correct oxygenation. Commercial-sized oysters, with a mean total weight of $67.8 \pm 9.78 \mathrm{~g}(\mathrm{SD})$, a mean total DW of $0.76 \pm 0.24 \mathrm{~g}(\mathrm{SD})$ and a mean soma DW of $0.63 \mathrm{~g} \pm 0.23(\mathrm{SD})$ and the same origin as in the previous experiments (Bourgneuf Bay, France), were stored for

5 weeks at $16^{\circ} \mathrm{C}$. The food supply (FWS) was adjusted to a concentration of $10^{6}$ cells. $\mathrm{mL}^{-1}$ of a culture of Skeletonema costatum with a flow of $10 \mathrm{~L} . \mathrm{h}^{-1}$ as the single fluid renewal. The device did not contain a biofilter as we hypothesised that the bacterial population harboured on the oyster shells was sufficient to carry out the nitrification process. Temperature, salinity, oyster biometry, TAN concentration and 
carbon concentrations were measured twice a week using the methods previously described. Finally, the TAN excretion equation and the PNR established in the present study were applied to this oyster stock to assess the nitrogen fluxes in the RAS.

Figure 1

\subsection{Statistical analysis}

Statgraphics Plus Centurion XV.I software (Sigma Plus, Paris, France) was used to check the normality and homoscedasticity of data distributions and for subsequent statistical analysis.

The excretion rates were estimated from the slope between TAN production rates and time, and for each condition, an averaged excretion rate was obtained from six individual measurements. A one-way ANOVA was performed to test effect of temperature on excretion rates, and a linear regression was subsequently applied to model the relationship between ammonia excretion and temperature.

For the second experiment, a t-test was performed to compare the PNR of the internal and the external surface of the shell. Where appropriate, Student-NewmanKeuls (SNK) tests were carried out a posteriori and one-way ANOVA was performed to test the stability of the nitrate concentration according to the experimental conditions. 


\section{Results}

\subsection{Experiment 1: TAN excretion measurement}

During the pre-experimental feeding, the food in the experimental tanks was supplied by the diatom Skeletonema costatum and corresponded to a mean carbon concentration of $0.65 \pm 0.55$ (SD) $\mathrm{mgC}^{-1} \mathrm{~L}^{-1}(\mathrm{n}=52)$. The mean $\mathrm{C} / \mathrm{N}$ ratio of the oysters was 5.92 corresponding to individuals with a low level of reserves. This was confirmed by the estimation of the weight of the soma which represented, on average, $85 \%$ of the total DW (Table 1 ).

The TAN excretion of the Pacific oyster varied between $0.23 \mu \mathrm{mol}$ TAN.h ${ }^{1}$.gDWsoma ${ }^{-1}$ at $13^{\circ} \mathrm{C}$ to $0.84 \mu \mathrm{mol} \mathrm{TAN}^{-1}{ }^{-1}$.gDWsoma ${ }^{-1}$ at $22^{\circ} \mathrm{C}$. However, significant differences were observed between each condition (SNK test, $p<0.05)$. A significant linear relationship was established between the excretion rate of Pacific oysters and temperature (ANOVA, $p<0.005)$ :

TAN $=-0.4663+\left(0.0547^{*}\right.$ Temp $)$

Figure 2

\subsection{Experiment 2: Potential nitrification rates}

The inhibition of the oxidation of nitrite into nitrate was successful since the nitrate concentration did not change during the experiment, whatever the conditions (oneway ANOVA, $F=0.52, p=0.84$ ) with a mean value of $33.72 \pm 6.24(S D) \mu m o l . L^{-1}$. Nitrite, however, accumulated linearly during 40 hours for the external and the internal surfaces of the shell (Fig. 3). The nitrite concentration was always higher for the external shell surface suggesting a more efficient nitrification process. The PNR was estimated by the slopes of each linear regression which showed a significantly 
higher flux for the external surface compared to the internal surface (t-test, $p<0.05$ ). For the PNR experiment, the mean shell surface areas of oysters (total weight of $59.2 \pm 6.6(\mathrm{SD}) \mathrm{g}$ ) was $73.63 \pm 6.14 \mathrm{~cm}^{2}$ for the internal surface and $102.10 \pm 8.14$ $\mathrm{cm}^{2}$ for the external surface. The PNR measured for the internal surface was $0.42 \pm$ $0.11 \mathrm{nmol} \mathrm{N} . \mathrm{cm}^{-2} \cdot \mathrm{h}^{-1}$ and $0.96 \pm 0.15 \mathrm{nmol} \mathrm{N} \cdot \mathrm{cm}^{-2} \cdot \mathrm{h}^{-1}$ for the external surface of the shell.

Figure 3

The daily PNR relative to the external surface represented $23.04 \mathrm{nmol} \mathrm{N} \cdot \mathrm{cm}^{-2} \cdot \mathrm{day}^{-1}$ and $10.08 \mathrm{nmol} \mathrm{N} . \mathrm{cm}^{-2}$.day ${ }^{-1}$ for the internal surface. The PNR linked to the internal surface of the shell represented $24 \%$ of the total flux $\left(742.19 \mathrm{nmol}^{\mathrm{ind}}{ }^{-1}\right.$.day $\left.\mathrm{d}^{-1}\right)$ while the major part was due to the external surface of the oyster shell with $76 \%(2352.4$ nmol.ind ${ }^{-1} \cdot$ day $\left.^{-1}\right)$. These data underline the importance of the shell surface area available for the settlement of a nitrifying bacterial population.

\subsection{Experiment 3: TAN concentrations in a RAS}

During the 5-weeks experiment, the temperature and salinity remained stable $\left(16.2^{\circ} \mathrm{C} \pm 0.11(\mathrm{SD}){ }^{\circ} \mathrm{C}\right.$ and $31.9 \pm 0.11$ (SD) $\left.\mathrm{PSU}\right)$ and the mean carbon concentration, measured as food descriptor, was $1.38 \pm 0.27$ (SD) $\mathrm{mgC}^{-1}$. The oyster mortality remained below $1 \%$. The TAN concentration measured in the RAS presented two phases (Fig. 4). The first one showed a rapid increase with a maximal concentration of $61.32 \mu \mathrm{mol} \mathrm{N.L}{ }^{-1}$ observed after 145 hours. This was followed by a decrease in the TAN concentration leading to a stable phase after 480 hours with a mean residual TAN concentration of $3.3 \pm 0.91$ (SD) $\mu \mathrm{mol} \mathrm{N} . \mathrm{L}^{-1}$. The concentration 
measured at this asymptotic phase can be compared with a theoretical calculation based on the application of the TAN excretion equation and the PNR established in the present study. Applied to the $180 \mathrm{~kg}$ oyster stock, the TAN excretion was 683.91 $\mu \mathrm{mol} \mathrm{N} \cdot \mathrm{h}^{-1}$ and the PNR was $342.31 \mu \mathrm{mol} \mathrm{N} \cdot \mathrm{h}^{-1}$ (PNR related to the surface of shells). The theoretical balance in TAN should lead to a residual of $341.60 \mu \mathrm{mol} \mathrm{N} \cdot \mathrm{h}^{-1}$

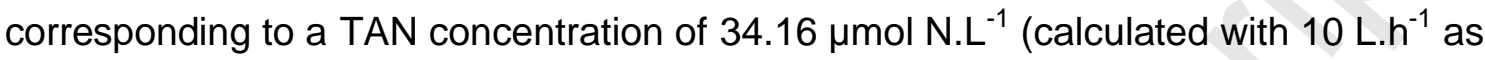
the flow renewal).

Figure 4

\section{Discussion}

\subsection{Experiment 1: TAN excretion measurement}

Ammonium is the primary $\mathrm{N}$-excretion product in bivalves. The effect of temperature on Pacific oyster TAN excretion was clearly demonstrated in this study and for the range of temperature determined as the operating conditions of a RAS. This result is consistent with most previous works on bivalve excretion (Bayne and Scullard, 1977; Boulter and Wilson, 1998; Shpigel et al., 1992). Our data on the TAN excretion rate are lower than those available in the literature for the oyster Crassostrea gigas (Table 2). This difference could partly be linked to the standardisation based in this study on the DW of soma while the cited authors used the total DW, which can increase the values by approximately $15 \%$. The highest value of excretion measured in this study $\left(0.85 \mu \mathrm{mol} \mathrm{N} . \mathrm{h}^{-1} . \mathrm{gDW}{ }^{-1}\right)$ was obtained at a temperature of $22^{\circ} \mathrm{C}$. This is one order of magnitude lower than the maximum value previously found for $C$. gigas (Shpigel et al.,1992, Table 2), but is consistent with the results obtained by Kesarcodi-Watson et al. (2001 a,b) for the oyster Saccostrea commercialis. Mao et al. (2006) measured a 
higher TAN excretion in the field but showed a strong variability according to the season, which included the variation of a large set of parameters such as food availability, temperature, oxygen consumption and gametogenesis of the oyster. Fiala-Medioni et al. (1983) obtained values three-fold higher than the maximum TAN excretion rate presented in this study, despite a lower pre-experimental temperature and food concentration and we hypothesize that this result could be explained by a longer acclimation period (10 to 15 days). Similarly, the highest value of Shpigel et al., (1992) was obtained with oysters fed for 35 days before TAN measurements. The present study was carried out with triploid oysters which do not invest or have a reduced energy investment in reproduction (Allen and Downing, 1986; Shpigel et al., 1992). Their energy allocation strongly limits gametogenesis, which reduces the risk of massive gamete release through spawning in the RAS. The effect of ploidy on oyster ammonia excretion is controversial in the literature. According to Shpigel et al., (1992), there was no significant difference in the ammonia excretion rate between triploid and diploid C. gigas oysters while Davis (1988) underlined that a lower nitrogen excretion contributed to a reduced metabolic cost for the triploids of the same species compared to diploid individuals. Kesarcodi-Watson et al. (2001b) similarly measured a significant difference for Saccostrea commercialis with an excretion $43 \%$ greater for diploid adults than triploid adults. The low excretion rate observed in this study could be partly related to the triploid status of the oyster (cf. Fiala-Medioni et al. (1983), Table 2).

Table 2

4.2 Experiment 2: Potential nitrification rates (PNR) 
Nitrification involves the oxidation of ammonia to nitrate. To estimate the PNR of the nitrifying populations, the last step of the nitrification process was inhibited to block the oxidation of the nitrites into nitrate and then to mesure its accumulation. For the nitrification of the TAN, the PNR of the external surface of the shell measured for the

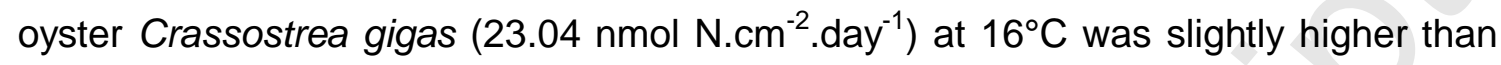
for other suspension-feeding bivalves such as Mytilus galloprovincialis and Tapes philippinarum whose PNR, at $20^{\circ} \mathrm{C}$, were $18 \pm 11.1$ and $26.5 \pm 7.8 \mathrm{nmol} \mathrm{N} . \mathrm{cm}^{-2} . \mathrm{day}^{-1}$, respectively, considering the difference in temperature (Welsh and Castadelli, 2004). This difference could be explained by the external structure of the shell which is much smoother for these bivalves compared to the oyster shell surface. On the other hand, the method used to assess the oyster shell surface probably underestimated the real surface area, given that, the crevices of the shells of the oysters were difficult to reach with the aluminium sheet. However, this study provides a first estimation of the potential nitrifying activity of the bacterial population carried by the oysters. The extrapolation of the results to an oyster population kept in a recirculating tank ( $n=2655$ individuals, mean total weight $( \pm S D): 67.8 \pm 9.78 \mathrm{~g})$, corresponding to a total surface area of $46.6 \mathrm{~m}^{2}$, gives a PNR estimation of $342 \mu \mathrm{mol} . \mathrm{h}^{-1}\left(83 \mu \mathrm{mol} . \mathrm{h}^{-1}\right.$ for the internal surface and $259 \mu \mathrm{mol} . \mathrm{h}^{-1}$ for the external surface). In these conditions, the specific surface area calculated was $360 \mathrm{~m}^{2} / \mathrm{m}^{3}$ which was comparable to the biofilters used in fish RAS that usually provide a specific surface area of between 100 and $300 \mathrm{~m}^{2} / \mathrm{m}^{3}$ (Pedersen et al., 2007; Timmons et al., 2006; Tseng and Wu, 2004). The estimation of the specific surface area enabled the efficiency of the biofilter to be assessed. It corresponded to the surface area of the medium available for bacteria growth per unit of volume (Timmons and Ebeling, 2007). 


\subsection{Experiment 3: TAN concentrations in a RAS}

In this study, we demonstrated the potential of oyster shells as a natural biofilter. This phenomenon was confirmed by additional experiments testing different oyster loads and food supplies (results not presented here). Even though, the quantitative estimations obtained here depend on RAS tested. General finding is that shells must be considered as potential biofilters for future up-scaling of RAS technology at the oyster farmer level.

The main TAN fluxes, i.e. production associated with oyster excretion and removal due to the PNR of the bacterial population, were extrapolated to an oyster population stored in a 1900 L RAS and compared with the experimental data. The theoretical balance resulting from the difference between these fluxes suggested that half of the excreted ammonia could be nitrified. However, this appeared a conservative estimate since the experimental TAN concentration measured in the RAS was an order of magnitude smaller $\left(34.60 \mu \mathrm{mol} \mathrm{N} . \mathrm{L}^{-1}\right.$ vs. $\left.3.3 \mu \mathrm{mol} \mathrm{N} . \mathrm{L}^{-1}\right)$. This indicated that the TAN flux from the bivalve excretion could be covered by the nitrification process resulting from the bacterial population harboured on the oyster shells. Nevertheless, the difference between the theoretical and measured TAN budgets highlighted that other fluxes probably contributed to the TAN budget. These additional fluxes could have been related to: a) the fluid renewal $\left(33 \mu \mathrm{mol} N . L^{-1}\right)$ within the RAS, b) the ammonification of the biodeposits and the remaining food accumulated in the system, c) the volatilisation of the ammonia (Lefebvre et al., 2001), and d) the nitrifying activity of other bacterial population from biofilms located on other compartments of the RAS like the biodeposits (Deslous-Paoli and Jousset, 1987) or the walls of the rearing tanks (Bourne et al., 2006). 
The evolution of the TAN concentration presented two phases (Fig. 4). During the first stage, the increasing TAN concentration can be attributed to the development of the nitrifying population. As the oysters were transferred from the sea to the RAS, this should induce a modification of the growing medium for the bacteria. Then, an adaptation period was necessary for this population harboured by the oysters to recover a fully efficient nitrifying activity. This maximal nitrifying activity was reached after 6 days followed by a decrease in the TAN concentration due to its oxidation into the nitrite form by another range of nitrifying bacteria (Khun et al., 2010). After 3 weeks, the stabilisation of the TAN concentration suggested that the recirculating aquaculture system had reached equilibrium and that the TAN production by the bivalves was not an issue for the system's water quality. For this steady-state, the TAN concentration measured of $3.3 \pm 0.91(\mathrm{SD}) \mu \mathrm{mol} N . \mathrm{L}^{-1}$ remained well below the critical level of $800 \mu \mathrm{mol} . \mathrm{L}^{-1}$ quoted by Epifanio and Srna (1975) as a threshold value beyond which oyster feeding processes are altered.

\section{Conclusion}

The TAN excretion calculated in this study appeared underestimated compared to the TAN concentration measured in the RAS. The comparison of the TAN fluxes for the Pacific oyster Crassostrea gigas underlines the key role played by the bacterial population colonizing the oyster shells. Its nitrifying efficiency suggests that an oyster stock could be stored in a RAS without the addition of a biofilter, which would represent a real economical advantage. The storage of an oyster stock of $180 \mathrm{Kg}$ was successfully tested for 5 weeks with a low mortality. This process may allow shellfish farmers to temporarily isolate their stock or a fraction of it to cope with unhealthy environmental conditions. However, the potential of oyster shells as 
natural biofilter demonstrated in this study must be confirmed by new replicated experiments before a transfer to oyster farmer level. This study represented a preliminary step to the modelling of nitrogenous fluxes in RAS dedicated to oyster storage, and other variables such as current speed and water renewal should be taken into account to complete this approach (Buzin, 2011).

\section{Acknowledgements}

The authors would like to thank two anonymous referees for their useful suggestions and we are grateful to R. Chagneau, oyster producer in the Polder of Bouin (Vendée, France) for his comments on the practical interest of a recirculating aquaculture system for the safeguard purposes. Florence Buzin was funded by a PhD grant from the Région des Pays de la Loire (France) and IFREMER. 


\section{REFERENCES}

Allen, J.S.K., Downing, S.L., 1986. Performance of triploid Pacific oysters, Crassostrea gigas (Thunberg). I. Survival, growth, glycogen content, and sexual maturation in yearlings. J. Exp. Mar. Biol. Ecol. 102, 197-208.

Alunno-Bruscia, M., Bourlès, Y., Maurer, D., Robert, S., Mazurié, J., Gangnery, A., Goulletquer, P., Pouvreau, S., 2011. A single bioenergetics growth and reproduction model for the oyster Crassostrea gigas in six Atlantic ecosystems. J. Sea Res. 66 (4), 340-348.

Aslan, S., Dahabb, M., 2008. Nitritation and denitritation of ammonium-rich wastewater using fluidized-bed biofilm reactors. J. Hazard. Mater. 156, 56-63.

Bacher, C., Baud, J-P, 1992. Intensive rearing of juvenile oysters Crassostrea gigas in an upwelling system: optimization of biological production. Aquat. Living Resour. 5, 89-98.

Barillé, L., Héral, M., Barillé-Boyer, A.-L., 1997. Modélisation de l'écophysiologie de l'huître Crassostrea gigas dans un environnement estuarien. Aquat. Living Resour. 10, 31-48.

Barillé L., Lerouxel A., Dutertre M.,Haure J., Barillé A-L., Pouvreau S., AlunnoBruscia M., 2011. Growth of the Pacific oyster (Crassostrea gigas) in a highturbidity environment: comparison of model simulations based on Scope For Growth and Dynamic Energy Budgets. J. Sea Res., 66 (4), 392-402.

Bayne, B.L., Scullard, C., 1977. Rates of nitrogen excretion by species of Mytilus (Bivalvia: Mollusca). J. Mar. Biol. Assoc. U. K. 57, 355-369.

Bayne, B.L., Newell, R.C., 1983. Physiological energetics of marine molluscs. In: Wilburg, K.M., Saleuddin, A.S.M. (Ed.), The Mollusca. Academic Press, London, pp. 407-515.

Bayne, B.L., Svensson, S., 2006. Seasonal variability in feeding behaviour, metabolic rates and carbon and nitrogen balances in the Sydney oyster, Saccostrea glomerata (Gould). J. Exp. Mar. Biol. Ecol. 332, 12-26.

Belser, L.W., Mays, E.L., 1980. Specific inhibition of nitrite oxidation by chlorate and its use in assessing nitrification in soils and sediments. Appl. Environ. Microb. $39,505-510$.

Belin, C. (2004). Bilan sur 20 ans des interdictions administratives de vente et de ramassage des coquillages, pour présence de phycotoxines, sur le littoral français 1984-2003).

Nantes

(France), 
http://envlit.ifremer.fr/infos/actualite/2004/bilan_des_interdictions_de_vente_d e_coquillages_pour_phycotoxines (Accessed on 03 June 2014).

Bendschneider, K., Robinson, R.J., 1952. A New Spectrophotometric Method for the Determination of Nitrite in Sea Water. J. Mar. Res. 11, 87-96.

Boardman, G.D., Starbuck, S.M., Li, X., Hudgins, D.B., Kuhn, D.D., 2004. Toxicity of Ammonia to Three Marine Fish and Three Marine Invertebrates. Environ. Toxicol. 19, 134-142.

Bougrier S., Geairon P., Deslous-Paoli J.M., Bacher C., Jonquieres G., (1995). Allometric relationships and effects of temperature on clearance and oxygen consumption rates of Crassostrea gigas (Thunberg). Aquaculture 134: 143154.

Boulter, M., Wilson, P., 1998. The use of physiological assessment techniques for determining the relative activity rates of bivalve shellfish during simulated depuration. J. Shellfish Res. 17, 1627-1631.

Boulter, M. et al., 1999. Depuration Centre Management, Revised Course Notes 1999. Seafish Industry Authority and Board lascaigh Mhara, pp. 210.

Bourne, D. G., L. Høj, et al. (2006). "Biofilm development within a larval rearing tank of the tropical rock lobster, Panulirus ornatus." Aquaculture 260 (1-4): 27-38

Briggs, M.R.P., Funge-Smith, S.J., 1994. A nutrient budget of some intensive marine shrimp ponds in Thailand. Aquacult. Fish. Manage. 25, 789-811.

Buzin, F. et al., 2011. Cold storage of Pacific oysters out of water: biometry, intervalval water and sensory assessment. Int. J. Food Sci. Technol. 46, 17751782.

Buzin F., 2011. Optimisation des conditions hydrobiologiques pour la conservation de l'huître creuse Crassostrea gigas en système recirculé. Thèse de doctorat de I'Université de Nantes, 174 p.

Chen, S., Ling, J., Blancheton, J.-P., 2006. Nitrification kinetics of biofilm as affected by water quality factors. Aquacult. Eng. 34, 179-197.

Colt, J.E., Armstrong, D.A., 1981. Nitrogen Toxicity to Crustaceans, Fish, and Molluscs. in: Allen, L.K., EC (Ed.), Bio-Engineering Symposium for Fish Culture. Bethesda, MD (USA) of the Fish Culture Section American Fisheries Society, Traverse City, MI (USA), pp. 34-47. 
Davis, J.P., 1988. Energetics of sterile triploid oysters uncouple the reproductive and somatic effort of diploids. J. Shellfish Res. 7, 114, Abstract.

De Abreu Corrêa, A. et al., 2007. Depuration dynamics of oysters (Crassostrea gigas) artificially contaminated by Salmonella enterica serovar Typhimurium. Mar. Environ. Res. 63, 479-489.

Deslous-Paoli, J.-M. and J. Jousset (1987). "Transformation of the faeces of Crassostrea gigas: Short-term biochemical changes." Océanis 13: 581-584.

Emerson, D.N., 1969. Influence of salinity of ammonia excretion rates and tissue constituents of euryhaline invertebrates. Comp. Biochem. Physiol. 29, 11151133.

Epifanio, C.E., Srna, R.F., 1975. Toxicity of Ammonia, Nitrite lon, Nitrate lon, and Orthophosphate to Mercenaria mercenaria and Crassostrea virginica. Mar. Biol. 33, 241-246.

FAO, 2009. Fisheries and Aquaculture Information and Statistics Service. Food and Agriculture Organization of the United Nations, Rome.

Fiala-Medioni, A., Copello, M., Colomines, J.C., 1983. Relations trophiques entre huître et milieu: influence de la concentration et de la taille des particules. Actes de Colloques $\mathrm{n}^{\circ 1}$. Bases biologiques de l'aquaculture. Ifremer, Montpellier, France, pp. 63-74.

Frias, R., Segovia, M., 2010. Gonad development of the Japanese oyster Crassostrea gigas in a recirculating system: First step toward the development of conditioning and maturation protocols. J. Shellfish Res. 29, 303-308.

Gnaiger, E., Bitterlich, G., 1984. Proximate biochemical composition and caloric content calculated from elemental $\mathrm{CHN}$ analysis: a stoichiometric concept. Oecologia. 62, 289-298.

Hammen, C.S., Miller, H.F., Geer W.H., 1966. Nitrogen excretion of Crassostrea virginica. Comp. Biochem. Physiol. 17, 1199-1200.

Keppler, C.J., 2007. Effects of ammonia on cellular biomarker responses in oysters (Crassostrea virginica). B. Environ. Contam. Tox. 78, 63-66.

Kesarcodi-Watson, A., Klumpp, D.W., Lucas, J.S., 2001a. Comparative feeding and physiological energetics in diploid and triploid Sydney rock oysters (Saccostrea commercialis): II. Influences of food concentration and tissue energy distribution. Aquaculture. 203, 195-216.

Kesarcodi-Watson, A., Lucas, J.S., Klumpp, D.W., 2001b. Comparative feeding and physiological energetics of diploid and triploid Sydney rock oysters, 
(Saccostrea commercialis): I. Effects of oyster size. Aquaculture. 203, 177193.

Kuhn, D. D., D. D. Drahos, et al. (2010). "Evaluation of nitrifying bacteria product to improve nitrification efficacy in recirculating aquaculture systems." Aquacult. Eng. 43(2): 78-82.

Lassus, P. et al., 2004. Paralytic shellfish poison outbreaks in the Penzé estuary: Environmental factors affecting toxin uptake in the oyster, Crassostrea gigas. Aquat. Living Resour. 17, 207-214

Lefebvre, S., Bacher, C., Meuret, A., Hussenot, J., 2001. Modelling Nitrogen Cycling in a Mariculture Ecosystem as a Tool to Evaluate its Outflow. Estuar. Coast. Shelf. S. 52, 305-325.

Losordo, T.M., Masser, M.P., Rakocy, J.E., 1999. Recirculating Aquaculture Tank Production Systems. A Review of Component Options, SRAC Publication, pp. 12.

Mao, Y., Zhou, Y., Hongsheng, Y., Wang, R., 2006. Seasonal variation in metabolism of cultured Pacific oyster, Crassostrea gigas, in Sanggou Bay, China. Aquaculture. 253, 322-333.

Marín Leal, J., Dubois, S., Orvain, F., Galois, R., Blin, J.-L., Ropert, M., Bataillé, M.P., Ourry, A., Lefebvre, S., 2008. Stable isotopes (d13C, d15N) and modelling as tools to estimate the trophic ecology of cultivated oysters in two contrasting environments. Mar. Biol. 153, 673-688.

Martins, C.I.M., Eding, E.H., Verdegem, M.C.J., Heinsbroek, L.T.N., Schneider, O., Blancheton, J.P., d'Orbcastel, E.R., Verreth, J.A.J., 2010. New developments in recirculating aquaculture systems in Europe: A perspective on environmental sustainability. Aquacult. Eng. 43, 83-93.

Méléder, V., Barillé-Boyer, A.-L., Baud, J.-P., Barillé, L., Cognie, B., Rosa, P., 2001. Modélisation de l'affinage de I'huître Crassostrea gigas alimentée avec la diatomée Skeletonema costatum. Aquat. Living Resour. 14, 49-64.

Pedersen, L.F., Pedersen, P.B., Sortkjær, O., 2007. Temperature-dependent and surface specific formaldehyde degradation in submerged biofilters. Aquacult. Eng. 36, 127-136.

Shpigel, M., Barber, B.J., Mann, R., 1992. Effects of elevated temperature on growth, gametogenesis, physiology, and biochemical composition in diploid and triploid Pacific oysters, Crassostrea gigas Thunberg. J. Exp. Mar. Biol. Ecol. 161, 15-25. 
Smaal, A.C., Vonck, A.P.M.A., 1997. Seasonal variation in C, N and P budgets and tissue composition of the mussel Mytilus edulis. Mar. Ecol. Prog. Ser. 153, 167-179.

Solorzano, L., 1969. Determination of ammonia in natural waters by the phenolhypochlorite method. Limnol. Oceanogr. 14, 799-801.

Timmons, M.B., Ebeling, J.M., 2007. Recirculating Aquaculture. Cayuga Aqua Ventures, Ithaca, NY.

Timmons, M.B., Holder, J.L., Ebeling, J.M., 2006. Application of microbead biological filters. Aquacult. Eng. 34, 332-343.

Tissot C., Brosset D., Barillé L., Le Grel L., Rouan M., Ion T., Le Tixerant M, 2012. Modeling oyster farming activities in coastal areas: a generic framework and preliminary application to a case study. Coast. Manage. 40, 484-500.

Tseng, K.-F., Wu, K.-L., 2004. The ammonia removal cycle for a submerged biofilter used in a recirculating eel culture system. Aquacult. Eng. 31, 17-30.

Shumway, S.E., 1990. A Review of the Effects of Algal Blooms on Shellfish and Aquaculture. J. World Aquacult. Soc. 21, 65-104.

Van Haren, R.J.F., Kooijman, S.A.L.M., 1993. Application of a dynamic energy budget model to Mytilus edulis (L.). Neth. J. Sea Res. 31, 119-133.

Welsh, D.T., Castadelli, G., 2004. Bacterial nitrification activity directly associated with isolated benthic marine animals. Mar. Biol. 144, 1029-1037.

Zimmo, O.R., Van der Steen, N.P., Gijzen H.J., 2003. Comparison of ammonia volatilization rates in algae and duckweed-based waste stabilization ponds treating domestic wastewater. Water Res. 37, 4587-4594. 


\section{Figure legends}

7 Figure 1. Diagram of the recirculating aquaculture system set up for the storage of

8 Pacific oyster Crassostrea gigas. Black arrow: water flow direction, HP: heat pump,

9 UV: ultraviolet lamp, FWS: Food and Water Supply, P: Pump, OP: Overflow Pipe,

10 ALS: Air Lift System, DP: Draining Pipe.

12 Figure 2: Effect of temperature on the Total Ammonia Nitrogen (TAN) excretion rate

13 of the oyster Crassostrea gigas. The physiological rate was standardized to the dry weight of soma (DWsoma) (see Material and Methods) $\left(p<0.05, r^{2}=0.88\right)$. Mean are presented with their standard deviation $(n=9)$.

17 Figure 3: Estimation of the Potential Nitrification Rates (PNR) of the bacterial 18 population colonizing the oyster shell. Nitrite accumulation is expressed per unit of 19 the internal $\left(\bullet, p<0.05, r^{2}=0.97\right)$ and the external $\left(\boldsymbol{\Lambda}, p<0.05, r^{2}=0.96\right)$ shell 20 surface area $\left(\mathrm{cm}^{2}\right)$. Mean are presented with their standard deviation $(\mathrm{n}=3)$.

22 Figure 4: Change in the Total Ammonia Nitrogen (TAN) concentration during the storage of a stock of $180 \mathrm{~kg}$ of Crassostrea gigas gigas in a $1900 \mathrm{~L}$ recirculating tank. 
24

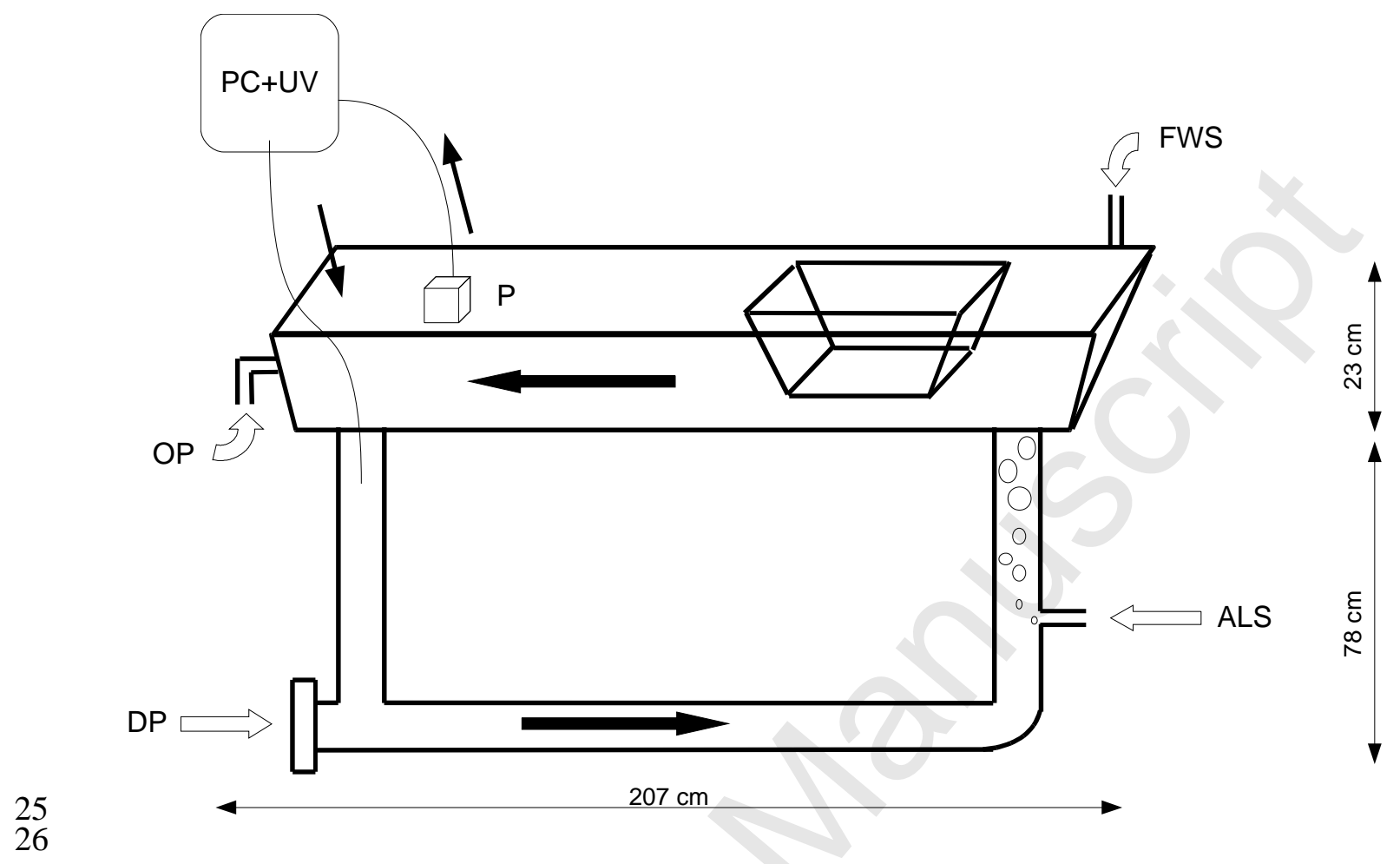

Figure 1

28 


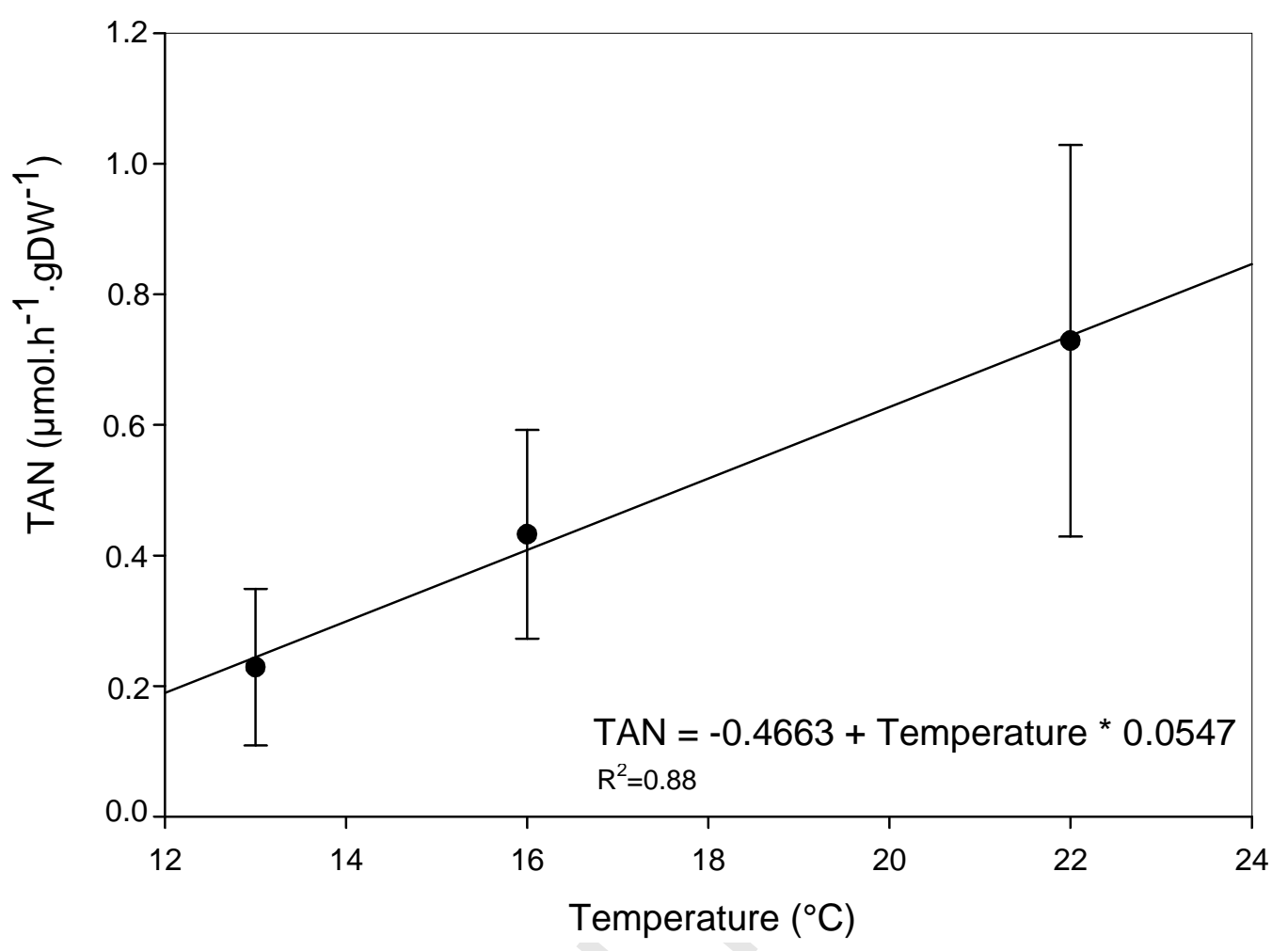

Figure 2 


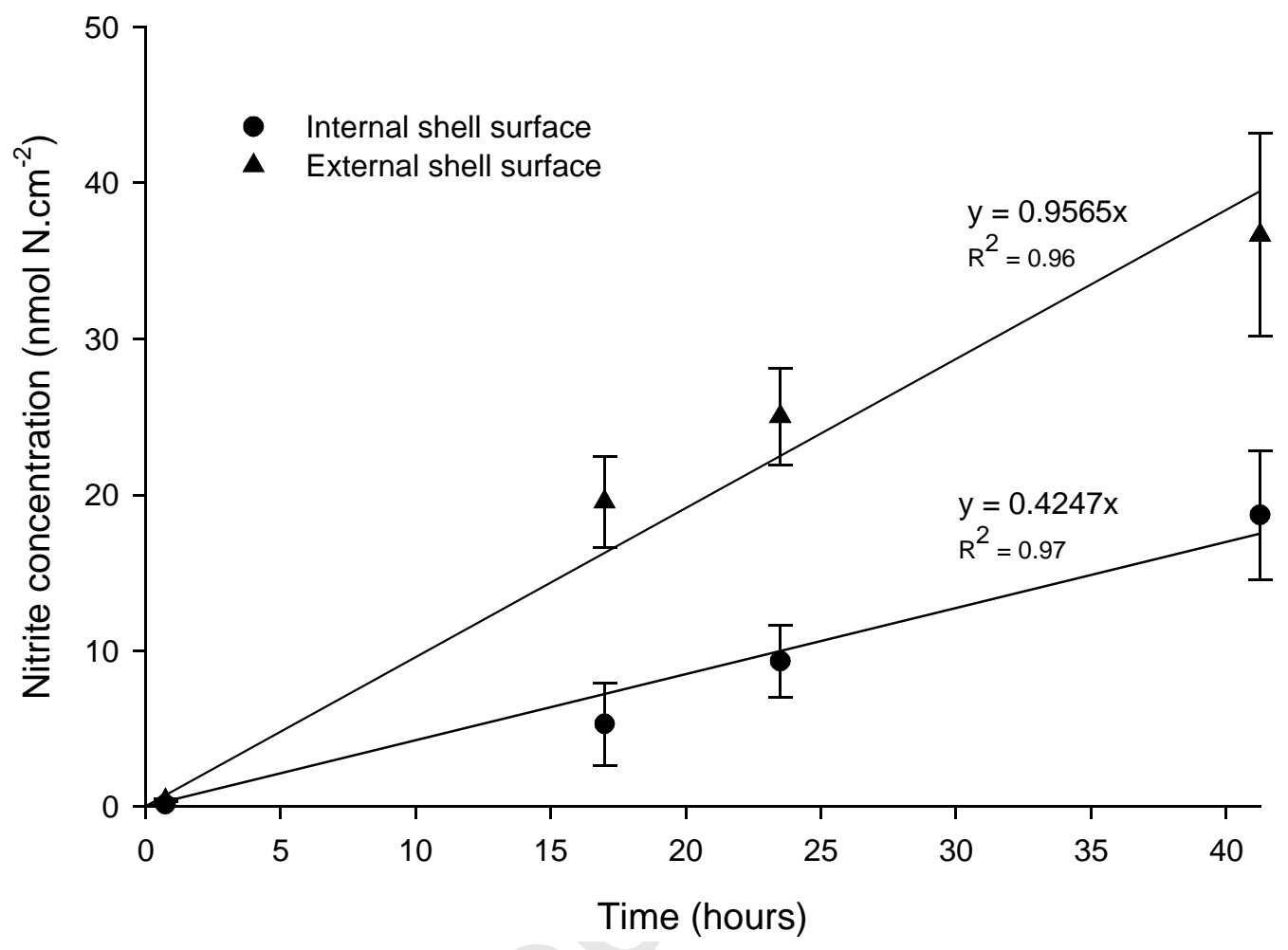

32

Figure 3

34 


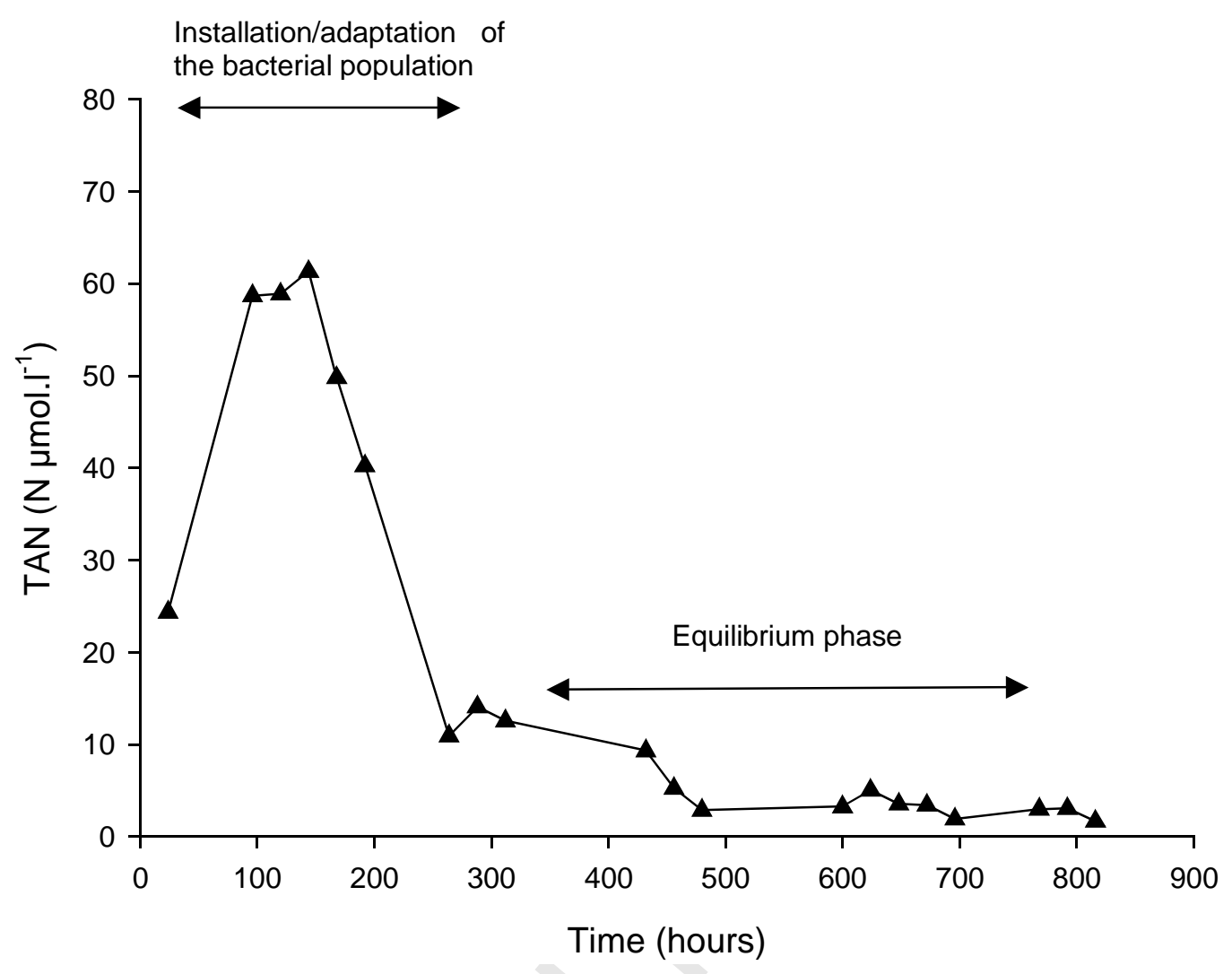

36

37

38

Figure 4

39 


\section{Highlights}

41 > Oyster shell harboured a bacterial population with nitrifying activity. > The PNR of 42 oyster shell was higher than for other suspension-feeding bivalves. > The TAN 43 excretion could be covered by the bacterial nitrifying activity. > Oyster stock could be 44 stored in a RAS without the addition of a biofilter. 


\section{TABLES:}

Table 1. Summary of the experimental conditions tested and excretion measurement results for Crassostrea gigas. For each condition, the number of oyster was $n=6$. For the oyster biometry, all variables are given with means and SD $(n=54) . C=$ carbon; $\mathrm{N}=$ nitrogen; $\mathrm{DW}=$ dry weight.

\begin{tabular}{ccc}
\hline Replicates & Temperature $\left({ }^{\circ} \mathrm{C}\right)$ & TAN excretion rate $\left(\mu \mathrm{mol}^{-1} \cdot \mathrm{gDWsoma}^{-1}\right)$ \\
\hline $\mathrm{C} 1$ & 13 & $0.24 \pm 0.07$ \\
$\mathrm{C} 2$ & 13 & $0.18 \pm 0.04$ \\
$\mathrm{C} 3$ & 13 & $0.23 \pm 0.07$ \\
\hline $\mathrm{C} 4$ & 16 & $0.33 \pm 0.10$ \\
$\mathrm{C} 5$ & 16 & $0.46 \pm 0.09$ \\
$\mathrm{C} 6$ & 16 & $0.48 \pm 0.21$ \\
\hline $\mathrm{C} 7$ & 22 & $0.43 \pm 0.16$ \\
$\mathrm{C} 8$ & 22 & $0.77 \pm 0.34$ \\
$\mathrm{C} 9$ & 22 & $0.84 \pm 0.20$ \\
\hline \multicolumn{3}{c}{ Oyster biometry } \\
$\mathrm{C} / \mathrm{N}$ & Total DW (g) & Soma DW $(\mathrm{g})$ \\
$5.92 \pm 0.63$ & $1.82 \pm 0.53$ & $1.52 \pm 0.37$
\end{tabular}


Table 2. Literature data of TAN excretion measured by different authors for the oyster Crassostrea gigas. n.a: not available, Chl a: chlorophyll a, C: carbon, * : oyster species, Saccostrea commercialis

\begin{tabular}{|c|c|c|c|c|}
\hline References & $\mu \mathrm{mol} \mathrm{N}-\mathrm{NH}_{4}{ }^{+} \cdot \mathrm{h}^{-1} \cdot \mathrm{gDW}^{-1}$ & Temperature $\left({ }^{\circ} \mathrm{C}\right)$ & Food supply & Ploidy \\
\hline Fiala-Medioni et al., 1983 & 2.81 & 15 & $0.016 \mathrm{mgC} . \mathrm{L}^{-1}$ & diploid \\
\hline Shpigel et al., 1992 & $8-9$ & $8-15$ & n.a & dipl/tripl \\
\hline Kesarcody et al., $2001 \mathrm{~b}$ & 2.14 & 23 & $2 \mathrm{mg} \mathrm{l}^{-1}$ of spray-dried microalgae & diploid \\
\hline Kesarcody et al., $2001 \mathrm{~b}$ & 1.22 & 23 & $2 \mathrm{mg} \mathrm{l}^{-1}$ of spray-dried microalgae & triploid \\
\hline Mao et al., 2006 & 5.4 & 23 & $1.73 \mu \mathrm{g} \cdot \mathrm{L}^{-1} \mathrm{Chl} a$ & n.a \\
\hline This study & 0.84 & 22 & $1.38 \mathrm{mgC} . \mathrm{L}^{-1}$ & triploid \\
\hline This study & 0.48 & 16 & $1.38 \mathrm{mgC} . \mathrm{L}^{-1}$ & triploid \\
\hline This study & 0.23 & 13 & $1.38 \mathrm{mgC} . \mathrm{L}^{-1}$ & triploid \\
\hline
\end{tabular}

